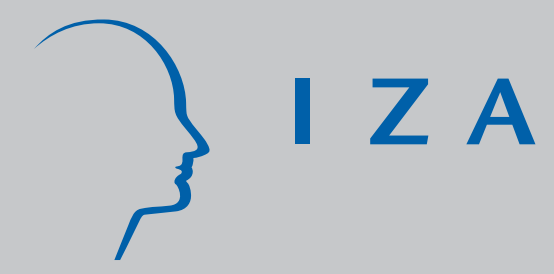

IZA DP No. 914

Bargained Wages, Wage Drift and

the Design of the Wage Setting System

Ana Rute Cardoso

Pedro Portugal

October 2003 


\title{
Bargained Wages, Wage Drift and the Design of the Wage Setting System
}

\author{
Ana Rute Cardoso \\ IZA Bonn, University of Minho, and CEPR \\ Pedro Portugal \\ Bank of Portugal and New University of Lisbon
}

\author{
Discussion Paper No. 914 \\ October 2003
}

\author{
IZA \\ P.O. Box 7240 \\ D-53072 Bonn \\ Germany \\ Tel.: +49-228-3894-0 \\ Fax: +49-228-3894-210 \\ Email: iza@iza.org
}

This Discussion Paper is issued within the framework of IZA's research area The Future of Labor. Any opinions expressed here are those of the author(s) and not those of the institute. Research disseminated by IZA may include views on policy, but the institute itself takes no institutional policy positions.

The Institute for the Study of Labor (IZA) in Bonn is a local and virtual international research center and a place of communication between science, politics and business. IZA is an independent, nonprofit limited liability company (Gesellschaft mit beschränkter Haftung) supported by Deutsche Post World Net. The center is associated with the University of Bonn and offers a stimulating research environment through its research networks, research support, and visitors and doctoral programs. IZA engages in (i) original and internationally competitive research in all fields of labor economics, (ii) development of policy concepts, and (iii) dissemination of research results and concepts to the interested public. The current research program deals with (1) mobility and flexibility of labor, (2) internationalization of labor markets, (3) welfare state and labor market, (4) labor markets in transition countries, (5) the future of labor, (6) evaluation of labor market policies and projects and (7) general labor economics.

IZA Discussion Papers often represent preliminary work and are circulated to encourage discussion. Citation of such a paper should account for its provisional character. A revised version may be available on the IZA website (www.iza.org) or directly from the author. 
IZA Discussion Paper No. 914

October 2003

\section{ABSTRACT \\ Bargained Wages, Wage Drift and the Design of the Wage Setting System*}

This paper aims at answering the question: How does a typically 'European' bargaining system - with collective bargaining, extension mechanisms and national minimum wage coexist with low unemployment rate and high wage flexibility? A unique data set on workers, firms and collective bargaining contracts in the Portuguese economy is used to analyze the determinants of both the bargained wage and the wage drift. Results indicate that wage drift stretches the returns to every worker and firm attribute, whereas it shrinks the returns to union bargaining power. Therefore, firm-specific arrangements, in the form of wage drift, partly offset collective bargaining, granting firms a high degree of freedom when setting wages. Union bargaining power raises the overall wage level, but lowers the returns on worker attributes, an outcome of the egalitarian policy pursued.

JEL Classification: D21, J31, J51

Keywords: wage distribution, wage drift, union bargaining power, employer coordination

Corresponding author:

Ana Rute Cardoso

IZA

P.O.Box 7240

53072 Bonn

Germany

Tel.: +49228 3894508

Fax: +492283894 180

E-mail: cardoso@iza.org

\footnotetext{
* Part of this work was carried out while the second author was visiting the Bank of Portugal, whose support is gratefully acknowledged. We thank Daniel Hamermesh, Alexandru Voicu and the participants in seminars held at Universidade NOVA de Lisboa, IZA Bonn, Tinbergen Institute and the LoWER network (Milan) for their suggestions. We are grateful to the Ministry of Employment, Statistics Department, for access to the data used in this paper. Lucena Vieira provided excellent research assistance. The usual disclaimer applies.
} 


\section{Introduction}

It has been extensively argued that labor market rigidities lead to unemployment. The major line of reasoning states that, under wage rigidity, negative shocks in the labor market will translate into adjustments of the employment level, thus generating unemployment. European collective bargaining institutions therefore have a poor reputation, since national minimum wages and minimum wages set by collective bargaining for different categories of workers can be sources of wage rigidity.

However, finer analyzes suggest that the impact of labor market institutions on macroeconomic performance depends crucially on the degree of centralization or coordination in the bargaining process. Nickell (1997) points out that a high level of coordination among employers in the bargaining process may lead to lower wage settlements and lower unemployment. Calmfors and Driffill (1988) highlight that highly centralized or highly decentralized bargaining systems lead to lower unemployment, whereas intermediate levels of centralization lead to the worst outcome. Teulings and Hartog (1998) claim that more centralized wage setting systems can be efficiency-enhancing. For Portugal, Hartog, Pereira and Vieira (2002) found that the level at which bargaining takes place has a significant impact on the wage distribution and on the returns to worker and firm attributes, and evidence on The Netherlands points in the same direction (Hartog, Leuven and Teulings, 2002). The impact of collective bargaining on the wage structure, wage rigidity and labor market performance is therefore not clear-cut.

The case of Portugal can shed interesting light on this issue. The country is pointed out as one of the OECD economies with highest wage flexibility (OECD, 1992), and it has one of the lowest unemployment rates in the European Union, despite having typically European labor market institutions: collective bargaining is widespread, setting the wages for unionized as well as non-unionized workers; once a collective agreement is signed, extension mechanisms can widen its coverage, voluntarily to employers or trade unions who had initially not signed the 
agreement, or by Government mandatory decision, irrespective of the workers' union membership status; a national minimum wage is enforced.

The aim of this paper is to answer the questions: What degree of freedom do employers have when manipulating wages in this regulated institutional setting? How does a regulated institutional framework in the labor market coexist with low unemployment rate and high wage flexibility? What is the impact of collective bargaining on the wage distribution?

Two novel aspects are introduced in the analysis of this topic. First of all, we rely on a micro data set that matches information on workers, firms, as well as collective bargaining contracts — over two million workers, 200 thousand firms, 500 collective bargaining agreements and 30 thousand worker categories in collective bargaining. Secondly, we analyze the determinants of both the contractual wage levels set by collective bargaining and the wage drift (difference between actual wages and bargained wages). As such, the impact of worker attributes, firm attributes and bargaining power on actual wages is decomposed into its impact on bargained wages and on wage drift. The analysis therefore progresses to the identification of the role of institutional forces versus market forces (firm-level arrangements) on wages.

Section 2 summarizes the institutional framework for wage bargaining in Portugal. Section 3 provides information on the data set and concepts used. Section 4 presents the results on the impact of the attributes of the worker, the firm and the bargaining process on contractual wages and on the wage drift. Section 5 discusses the question "What do results tell about a formal model of wage bargaining?", scrutinizing the existence and the impact of trade unions egalitarian pay policies. Section 6 concludes.

\section{Institutional framework for wage bargaining in Portugal: what room for firm manoeuvre?}

Portugal shares with several other European countries characteristics of a regulated industrial relations system, in contrast with the American model. Several aspects 
can be highlighted to support this claim.

- Degree of centralization in collective bargaining: Massive collective agreements, often covering a whole industry, predominate in the economy, while firm level collective bargaining covers a low proportion, less than 10 percent, of the workforce. Also, centralized negotiations at the national level have been taking place each year since 1984, between trade union confederations, employers' federations and the Government. This level of bargaining sets indicative guidelines for wage increase, which orient the collective bargaining that follows.

- The role of extension mechanisms: Extension mechanisms are widespread in the economy. Voluntary extensions are common, when one economic partner —workers' or employers' representative - decides to subscribe to an agreement which it had initially not signed. Compulsory extensions can be applied by the Government, when the bargaining partners fail to reach an agreement, when bargaining is obstructed in any way or workers are not covered by a trade union. Therefore, the impact of collective bargaining goes far beyond union membership and the distinction between unionized and non-unionized workers or firms becomes meaningless.

- Frequency of wage adjustments and synchronization of bargaining: The negotiation of different collective agreements is usually synchronized, taking effect in January each year.

- Contents of the agreements: Since most collective agreements are industrywide, covering companies with very different sizes and economic conditions, their contents tend to be general, setting minimum working conditions, in particular the base monthly wage for each category of workers, overtime pay and the normal duration of work. Moreover, just a narrow set of topics is updated annually, and therefore the contents of collective agreements is often pointed out as being too immobile and containing little innovation (see 
Dornelas (1999) and Leitão (1999)). ${ }^{1}$

Under these conditions, the links between the wage growth defined by collective agreements and the actual economic conditions prevailing at the micro (firm) level can be very loose. Whatever the minimum wage level agreed upon for each category of workers at the collective bargaining table, firms are free to pay higher wages, and they often deviate from that benchmark, adjusting it to firm specific conditions.

\section{$3 \quad$ Data set and concepts used}

\subsection{Data set}

This study is based on a longitudinal data set matching firms and workers, which covers the population of plants with wage-earners in manufacturing and the services private sector in Portugal. The data are gathered every year by the Ministry of Employment. Given the legally binding nature of the inquiry, the response rate is extremely high. Reported data include the firm's location, industry, employment, sales, ownership, legal setting, and the worker's gender, age, skill, occupation, schooling, date of admission into the company, earnings, duration of work, as well as the mechanism of wage bargaining and the category in collective bargaining (see the appendix for details on the data).

\subsection{Computation of the contractual wage}

In the Portuguese collective bargaining system, minimum contractual wages are defined for very specific job classifications. Given this fact, a majority of the workforce in each category will actually earn the minimum contractual wage that has been set by collective bargaining.

We have used this information to infer the contractual wage from the distribution of actual base-wages for each worker category. In fact, the mode of the distribution of the base wage corresponds with remarkable accuracy to the contractual wage set by collective bargaining. To prove this claim, we have extensively

\footnotetext{
${ }^{1}$ Dornelas (1999) points out that they seldom deal with health, hygiene and security in the workplace, training and its impact on career progression, and social protection beyond the minimum compulsory one.
} 
checked the relationship between contractual wages and the mode of the wage distribution for each worker category within each collective agreement, for a set of industries chosen a-priori. Each of these industries covers a large proportion of the working population, and they have contrasting wage levels:

- Textiles - cotton and knitted fabrics is a low-wage industry;

- Electric and electronic goods industry is a high-wage industry;

- Banking is a high-wage service industry.

Note that the number of workers in the selected industries (see table 1) represent almost $10 \%$ of the full-time wage-earners in manufacturing and the services.

Table 1 about here

For this set of industries we have gathered the contractual wages for 1999 and 1998 for each worker category from the legal published documents (Boletim do Trabalho e do Emprego), and compared them to the mode of the distribution of the actual base wage. The results can be summarized as follows:

- The correlation between the contractual wages set by collective bargaining and the mode of the base-wage is very high, ranging from 99 percent to 77 percent, respectively in the banking sector and the textiles industry in 1999 (see table 2). Visual inspection of the relationship between the contractual wage and the mode of the base wage is presented in figure 1. Each circle represents one worker category and its area is proportional to the number of workers covered. The accuracy of the modal base-wage as an indicator of the bargained wage is striking.

- For a very high proportion of the working population, the contractual wage set by collective bargaining is exactly equal to the mode of the distribution of the base-wage. Such proportion ranges from 97 percent to 74 percent, respectively in the banking sector in 1999 and the electric and electronic equipment industry in 1998 (see figure 2). 
Following these results, throughout this paper the mode of the base-wage for each worker category within each collective agreement will be taken as the contractual wage for that professional category. ${ }^{2}$ Just categories that cover at least 50 workers and agreements with at least one thousand workers will be kept in the analysis. The sample sizes are described in table 3 in appendix.

Table 2 about here

Figure 1 about here

Figure 2 about here

\subsection{Computation of the wage drift}

Wage drift was computed following the standard procedure in the literature (see for example Hibbs and Locking (1996) or Ordine (1996)), as the log difference between the current actual wage and the contractual wage:

$$
\text { wrift }_{i t}=\log \left(\frac{\text { wactual }_{i t}}{\text { wbarg }_{i t}}\right)
$$

where $i$ stands for the worker, $t$ for the time period, wactual is overall monthly earnings, including the base-wage, tenure-related and other regularly paid components; wbarg stands for the contractual wage defined for the worker category by collective bargaining.

\footnotetext{
${ }^{2}$ Since the wages set by collective bargaining are binding, one other possibility to infer the bargained wage would be to consider the minimum base-wage observed in the data set for each worker category. However, workers who worked less than the full month - for example, due to sickness or because their contract started later in the month - may earn less than the bargained wage. In such a large sample of the working population, that method would therefore be bound to capture the wrong value. Still another approach has been checked, which consisted on identifying the bargained wage as the first peak in the distribution of the base-wage, i.e. the first point after which the density function declined. However, this procedure is subject to the same drawbacks as the previous one. Computing the bargained wage as the mode of the base-wage provided a more accurate value than any of these two procedures.
} 


\section{Explaining the contractual wage and the actual wage at the micro level}

The average wage drift by industry ${ }^{3}$ in 1999 ranged from 0.20 in hotels and restaurants to 0.47 in the pulp, paper and printing industry (see table 4).

Table 4 about here

As expected, wage drift has a ed-equalizing impact on the wage distribution. Indeed, it leads to higher wage dispersion than that of bargained wages. Also according to expectations, the drift is particularly heterogenous at the top half of the distribution, being more homogeneous for the lower bottom (see table 5).

Table 5 about here

Looking at the degree of association between bargained wages and the wage drift, actual wages and their dispersion, at different levels of aggregation, yields a pattern worth mentioning (see table 6). Professional categories with higher bargained wages tend to present lower dispersion of the wage drift (and therefore lower dispersion of the actual wage, since all the wage variability within a category results from wage drift). Similarly, at the level of the collective bargaining agreement, higher average bargained wages are associated with lower dispersion of both the wage drift and the actual wage.

Table 6 about here

Which are the determinants of the contractual wages agreed upon with trade unions, and how do these differ from the determinants of the actual wage that is paid? Do collective bargaining outcomes reflect the bargaining power of the partners involved, whereas wage drift reflects market conditions?

The regressions presented in table 7 explore the impact of worker attributes, firm attributes and the collective bargaining system on bargained wages and on

\footnotetext{
${ }^{3}$ Two-digit classification.
} 
wage drift. On the worker and employer side, the usual determinants of wages have been considered: the worker gender, schooling, age and tenure; the firm size, age, average gross labor productivity and gross job flow ${ }^{4}$. Controls for the industry and the region have been included in every regression.

The variables that characterize the institutional setting are less often found in the empirical literature. The degree of coordination of employers in wage bargaining and the degree of trade union power will deserve particular attention in the interpretation of the results. The degree of coordination of employers results simply from the definition of the types of collective agreement existing in Portugal: single-firm agreement; multi-firm agreement, signed by several employers, though not organized into a formal association; sector agreement, signed between employers' association(s) and trade union(s), often covering an economic sector. Also, the Government can impose a mandatory regime, as described in section 2.

The degree of union bargaining power is captured by the concentration of bargaining within an occupation, firm or region. Those proxies are based on the idea that, if the labor force is more united in the bargaining process, it will have a stronger bargaining power. Recent experimental evidence in Berninghaus, Guth and Keser (2003) indeed indicates that, when opting for collective bargaining instead of decentralized bargaining, united players raise their claim for a share of the pie (even though their payoff might not be larger, if the occurrence of conflicts increases), and the opponent lowers its claims. The Herfindhal index was used to evaluate the degree of concentration of bargaining within an occupation, firm or region. ${ }^{5}$ If one single collective agreement covers all the workforce in the occupation, the firm or the region, the index reaches the value one, interpreted as a high degree of union power within that occupation, firm or region. On the contrary, a fragmented bargaining process, with workers represented by several trade unions bargaining separately, leads to a low value of the Herfindhal index and suggests

\footnotetext{
${ }^{4}$ Computed as $g_{f}=\frac{\Delta E_{f t}}{\frac{1}{2}\left(E_{f t}+E_{f, t-1}\right)}$, where $E$ stands for employment level, $f$ refers to the firm and $t$ is the time period.

${ }^{5}$ It is computed as $H_{j}=\sum_{i}\left(\text { share }_{i j}\right)^{2}$, where share $_{i j}$ is the share of workers covered by collective agreement $i$, within unit $j$ (defined as an occupation at the 4-digit level, yielding 402 occupations, a firm or a region, defined at a detailed level, yielding 18 regions in mainland Portugal).
} 
less union strength.

We have estimated tobit models on the wage bargained, the wage drift and, a result of the two previous forces, the actual wages paid. This choice is justified by the fact that contract wages cannot fall below the national minimum wage, and actual wages cannot fall below the contract wage defined for the worker category.

It is interesting to note, first of all, that wage drift reinforces the impact of worker and firm attributes on wages. Note that the signs of those coefficients are the same, in the bargained wage and the wage drift regressions. In other words, wage drift stretches the distribution of the returns to education, gender, age, tenure, firm size, firm productivity or firm-level worker turnover (rate of job creation or destruction). On the contrary, variables that capture the bargaining power of trade unions have a high impact on bargained wages, but that impact is partly offset by wage drift. In fact, the concentration of bargaining within an occupation or within a firm become less relevant in the determination of actual wages than they were in the determination of bargained wages. In other words, wage drift shrinks the distribution of returns to union bargaining power.

The previous results lend support to the hypothesis that wage drift works as a mechanism to overcome the constraints imposed by collective bargaining, allowing firms wide scope for action in their wage policy.

The impact of the extent of union power deserves further comment. Higher coordination on the side of the workers along occupation or firm lines is associated with higher wages. If the degree of concentration of bargaining within an occupation increases by 10 percentage points, the bargained wage increases by about $1 \%$. Similarly, a more united labor force bargaining within the firm raises bargained wages: an increase of 10 percentage points in the degree of concentration of bargaining within a firm raises bargained wages by approximately $2 \%$. These results suggest that the fragmentation of bargaining reduces union capacity to extract rents. 
However, as mentioned before, these returns on union bargaining power are offset by firm-specific wage arrangements, in the form of wage drift. In the end, the concentration of bargaining within the occupation or the firm has a very low impact on the actual wages paid.

The interpretation of the results on the geographical coverage of the agreements is not as clear-cut. On one hand, agreements covering a wider area are associated with lower bargained wages, possibly because unions are in that case unable to fully exploit local labor market conditions. On the other hand, as opposed to the results for the occupation and firm, more fragmented wage bargaining within the region lead to higher wage settlements, a result that is reinforced by wage drift.

On the employer side, higher coordination when bargaining over wages is associated with lower wages. Indeed, single-firm or multi-firm agreements yield higher bargained wages than sector-level agreements. Even though the rank of the type of agreement changes after wage drift operates, it is still the case that single-firm and multi-firm agreements yield higher wages than sector agreements. These results lend support to the reasoning by Nickell (1997), according to which the coordination of employers leads to lower bargained wages, reducing the impact of collective bargaining on unemployment.

The positive impact of the firm's gross job creation rate and its average labor productivity on the bargained wage is consistent with the results by Christofides and Oswald (1992), who analyzed the impact of industry and regional variables on wages bargained in a sample of labor contracts in Canada, and found evidence that wage determination is a rent-sharing mechanism. Their work found that higher profits in the industry enable unions to extract a higher rent in the form of higher bargained wages, whereas a depressed labor market, with a higher regional unemployment rate, decreases bargained wages. 


\section{What do results tell about a formal model of collective bargaining?}

The results so far presented are compatible with two different situations in terms of trade union action and formal models of bargaining. On one hand, it could be the case that trade unions have in Portugal a low bargaining power, being unable to extract a high return on worker attributes. Willingness of companies to pay a higher wage premium would thus be revealed only after the stage of collective bargaining, in the form of wage drift operating at the firm level. On the other hand, it could be the case that unions, though having a high bargaining power, have strong equalizing aims, explicitly trying to compress the returns to worker attributes. As such, they would use their bargaining power to set a higher overall wage level, but a lower return on worker attributes.

Several empirical studies using cross-section worker data have indeed shown that trade unions reduce wage dispersion, in particular because the returns to worker attributes are lower in the unionized sector (Freeman, 1980) (Fairris, 2003) (Meng, 1990), just like the returns to firm attributes (Dell'Aringa and Lucifora, 1994). However, the impact of union action on wages could partly result from selectivity, if the worker unobservable quality is correlated with the unionization status, a problem that can only be tackled using longitudinal data. Longitudinal studies may, however, underestimate the impact of trade unions on wages, if there is measurement error in the variable union status (Freeman, 1984). Explicitly accounting for selectivity and measurement error in union status, Card (1996) showed that unions compress the wage distribution by raising more the wages of low-skilled workers. Part of this result is driven by a selection mechanism: union members with low observable skills have higher unobservable quality than non-union-members; conversely, union members with high observable skills have lower unobservable quality than non-union-members. Lemieux (1998) allowed the returns to worker observable attributes and unobservable quality to differ in the unionized and non-unionized sectors. Interestingly, he finds that unions raise the 
average wage level, but compress the returns to both observable and unobservable worker quality. The finding by the empirical literature that unions reduce wage dispersion, in particular by lowering the returns on human capital, therefore seems robust.

Theoretical models explicitly handling the role of wage dispersion in union preferences are, however, scarcer. The models by Farber (1978) and Booth (1984) handle trade unions egalitarian aims by considering that they are political units, whose policies will determine workers support for the union leaders or their membership decision. As such, union leaders will choose to bargain for the wage that maximizes the utility of the median voter. If the median wage is below the mean wage, as it is commonly the case, a majority of workers will favor a policy that compresses the wage distribution. According to Agell and Lommerud (1992), there is an insurance rationale for wage compression. If risk-averse workers face uncertainty about their future position in the wage distribution, and the market fails to provide insurance against wage risks, then workers will support wage compression. Rodríguez-Gutiérrez (2001) directly introduces the degree of wage dispersion into the union utility function, based on the assumption that unions obtain utility from wage compression.

The two hypothesis put forth to explain the results on Portugal - the existence of a low union bargaining power or an explicit aim by unions to reduce the returns on worker attributes - , can be disentangled, within the framework of the current paper, by running the previous regression of bargained wages with interaction terms between every worker attribute and a measure of union power (the concentration of bargaining within occupations) among the regressors. The coefficients on those interaction terms would enable an answer to the question: Do trade unions use their bargaining power to lower the returns on worker attributes, while nevertheless raising the overall wage level?

Table 8 about here

Result in table 8 provide support for the egalitarian pay policy hypothesis. 
They show that trade unions use their power to raise the overall wage level (see the coefficients on the concentration of bargaining within the occupation or firm), and to reduce the wage penalty imposed on women and newcomers into the firm (see the positive coefficients on the interactions of each of these variables with the index of trade union power). On the contrary, a higher union bargaining power is associated with lower returns on schooling, age and tenure. The low returns to worker attributes set by collective bargaining do not result from a lack of union power, but instead result from an explicit aim of compressing the wage distribution, while raising the overall wage level.

\section{Conclusion}

Most often, micro level analysis of the returns to worker and firm attributes have considered only the actual wage of the worker. This study has progressed along two directions. First of all, we have decomposed the worker's actual wage into the wage set by collective bargaining and firm-specific wage arrangements, in the form of wage drift. Secondly, we have analyzed the impact of, not just worker and firm attributes, but also characteristics of the wage setting process, on wages. In particular, we focused on the impact of union bargaining power and the degree of employer coordination on the wage distribution.

We found that the distribution of wages set by collective agreements reflects to a high extent the bargaining power of the partners negotiating, and as such higher coordination among employers tends to be associated with lower wages, whereas a more united labor force bargaining within an occupation or firm raises the overall wage level, while reducing the returns to worker attributes, an indication of the strong equalizing aims pursued by trade unions. However, wage drift work as a mechanism to overcome the constraints imposed by collective bargaining, allowing firms wide scope for action in their wage setting policy. Indeed, wage drift reinforces the impact of worker and firm attributes on wages, while, on the contrary, it dilutes the impact of collective bargaining. Wage drift stretches the distribution of the returns to education, gender, age, tenure, firm size, firm age 
and firm productivity whereas, on the contrary, it shrinks the returns to union bargaining power. This operation of institutional forces and market forces in the Portuguese economy may help explain why a typically European institutional framework is compatible with high wage flexibility and low unemployment.

\section{Appendix: Data set}

Quadros de Pessoal gathers information on workers, firms and collective bargaining contracts in the Portuguese private sector. In this study, only wage-earners reported as full-timers and working at least 25 hours a week, aged 16 to 65, earning at least the national minimum wage, in manufacturing and the services in mainland Portugal, were considered for analysis. The national minimum wage constraint may drop workers in particular categories, such as apprentices and youngsters below the age of 18 .

Only collective agreements effective before October (the date the data were gathered) were retained for analysis. Given that we are computing the bargained wage as the mode of the distribution of base-wages for each category of workers, the categories considered in the analysis should cover a certain number of workers. Categories with at least 50 workers and agreements with at least one thousand workers were kept for analysis.

Table 3 about here

Table 9 about here

The data base reports the gross monthly wage, split into the following components: base wage, seniority-indexed components of pay, other regularly paid components, overtime work and irregularly paid components. Normal and overtime hours of work are as well reported. Minimum contractual wages are defined in Portugal as a monthly wage rate. 


\section{References}

Agell, Jonas And KJell Erik Lommerud (1992). Union egalitarianism as income insurance. Economica, 10(59)235: 295310.

Berninghaus, Siegfried, Werner Guth And Claudia Keser (2003). Unity suggests strength: an exprimental study of decentralized and collective bargaining. Labour Economics, 10(4): 465-479.

Booth, Alison (1984). A public choice model of trade union behaviour and membership. Economic Journal, 94: 883-898.

Calmfors, Lars and John Driffill (1988). Centralization of wage bargaining. Economic Policy, 6: 13-47.

CARD, DAvid (1996). The effect of unions on the structure of wages: a longitudinal analysis. Econometrica, 64(4): 957-979.

Christofides, Louis N. And Andrew J. Oswald (1992). Real wage determination and rent-sharing in collective bargaining agreements. Quarterly Journal of Economics, 107(3): 985-1002.

Dell'Aringa, Carlo and Claudio Lucifora (1994). Wage dispersion and unionism: do unions protect low pay? International Journal of Manpower, 15(2/3): 150-169.

Dornelas, António (1999). As relações industriais em Portugal: É possível mudar? É possível não mudar? Sociedade e Trabalho, 7: 19-28.

FAIRris, DAVID (2003). Unions and wage inequality in Mexico. Industrial and Labor Relations Review, 56(3): 481-497.

FARBER, Henry S. (1978). Individual preferences and union wage determination: the case of the United Mine workers. Journal of Political Economy, 86(5): 923-942. 
Freeman, Richard B. (1980). Unionism and the dispersion of wages. Industrial and Labor Relations Review, 34(1): 3-23.

Freeman, Richard B. (1984). Longitudinal analyses of the effects of trade unions. Journal of Labor Economics, 2(1): 1-26.

Hartog, Joop, Edwin Leuven And Coen Teulings (2002). Wages and the bargaining regime in a corporatist setting: the Netherlands. European Journal of Political Economy, 18: 317-331.

Hartog, Joop, Pedro T. Pereira And José A. C. Vieira (2002). Bargaining regimes and wages in Portugal. Portuguese Economic Journal, 1(3): 237-258.

Hibbs JR., Douglas A. And Hakan Locking (1996). Wage compression, wage drift and wage inflation in Sweden. Labour Economics, 3: 109-141.

Leitão, Maria Josefina Menezes (1999). Traços gerais da contratação colectiva em Portugal. Sociedade e Trabalho, 4: 19-28.

Lemieux, Thomas (1998). Estimating the effects of unions on wage inequality in a panel data model with comparative advantage and nonrandom selection. Journal of Labor Economics, 16(2): 261-291.

Meng, Ronald (1990). Union effects on wage dispersion in Canadian industry. Economics Letters, 32: 399-403.

Nickell, Stephen (1997). Unemployment and labor market rigidities: Europe versus North America. Journal of Economic Perspectives, 11(3): 55-74.

OECD [Organisation for Economic Co-operation and Development] (1992). OECD Economic Surveys, Portugal, 1991/92. Paris: OECD.

Ordine, Patrizia (1996). Wage drift and minimum contractual wage: theoretical interrelationship and empirical evidence for Italy. Labour Economics, 2: 335-357. 
Portugal, Ministério do Trabalho e da Segurança Social (1998 and 1999). Quadros de Pessoal. Data in magnetic media.

Rodríguez-GutiérRez, CÉSAR (2001). Wage dispersion within firms and collective bargaining in Spain. Economics Letters, 72: 381-386.

Teulings, Coen And Joop Hartog (1998). Corporatism or Competition? Cambridge: Cambridge University Press. 


\begin{tabular}{|r||c|c|c|c|}
\hline \multicolumn{1}{|c||}{} & \multicolumn{4}{c|}{ Full-time wage-earners } \\
\hline \multicolumn{1}{|c||}{ Industry } & 1998 & 1999 & 1998 & 1999 \\
\hline \hline \multicolumn{1}{|c|}{ Banking } & 60,922 & 63,599 & 53,291 & 54,502 \\
Electric and electronic equipment & 38,832 & 42,870 & 23,951 & 29,717 \\
Textiles: cotton and knitted fabrics & 72,518 & 72,407 & 52,849 & 53,240 \\
\hline
\end{tabular}

Table 1: SAmple sizes When CheCKING the PRocedure to COMPUTE the CONTRACTUAL WAGE.

Note: The sample selected covers full-time wage-earners in professional categories with at least 50 workers, with category and contractual wage unambiguously defined. Source: Computations based on Portugal, MTSS (1998-1999).

\begin{tabular}{|r||c|c|}
\hline Industry & 1998 & 1999 \\
\hline \hline Banking & 0.992 & 0.994 \\
Electric and electronic equipment & 0.885 & 0.949 \\
Textiles: cotton and knitted fabrics & 0.834 & 0.768 \\
\hline
\end{tabular}

Table 2: Correlation Between Contractual Wages and the mode of the Base-Wage FOR THE WORKER PROFESSIONAL CATEGORIES.

Note: Weight equal to size of professional category. Source: Computations based on Portugal, MTSS (1998-1999) and Boletim do Trabalho e Emprego (several numbers).

\begin{tabular}{|r||c|c|c|c|}
\hline Sample size & workers & firms & agreements & categories \\
\hline \hline Total employer-employee data set & $2,568,456$ & 242,026 & 531 & 30,659 \\
Ftimers, 16-65 yrs, manuf \& serv., w $>=$ min & $1,644,550$ & 172,372 & 385 & 24,114 \\
Col. barg. categories $>=50$ workers & $1,462,932$ & 165,795 & 232 & 3,871 \\
Col. barg. agreements $>=1000$ workers & $1,438,699$ & 162,604 & 133 & 3,662 \\
\hline
\end{tabular}

Table 3: SAMPle Sizes in the ANALYSIS OF WAGE BARGAINED AND WAGE DRIFT, 1999. Source: Computations based on Portugal, MTSS (1999). 


\begin{tabular}{|r||c|}
\hline Industry & Av. wage drift \\
\hline \hline food, bev, tobacco & .300 \\
textiles, wearing app, leather & .233 \\
wood & .265 \\
pulp, paper, printing & .465 \\
petroleum prod, chemicals, rubber, plastic & .435 \\
other non-metallic mineral prod & .327 \\
basic metals, fabricated metal products & .326 \\
machinery, equipment & .338 \\
other manufacturing & .241 \\
electricity, gas, water supply & .362 \\
construction & .298 \\
trade & .383 \\
hotels, restaurants & .199 \\
transportation, storage, communication & .352 \\
financial intermediation & .456 \\
real estate, business activities & .402 \\
\hline
\end{tabular}

Table 4: Average Wage DRIFt By Industry, 1999. Source: Computations based on Portugal, MTSS (1999).

\begin{tabular}{|r||c|c|c|c|}
\hline & Gini & $Q 90 / Q 10$ & $Q 50 / Q 10$ & $Q 90 / Q 50$ \\
\hline \hline Bargained wage & 0.228 & 2.45 & 1.25 & 1.96 \\
Wage drift & 0.199 & 2.06 & 1.27 & 1.62 \\
Actual wage & 0.319 & 3.64 & 1.47 & 2.48 \\
\hline
\end{tabular}

Table 5: Dispersion of Bargained Wages, Wage drift and ACtual Wages, 1999. Source: Computations based on Portugal, MTSS (1999).

\begin{tabular}{|r||c|c|}
\hline & $\begin{array}{c}\text { Professional category } \\
\text { barg. wage }\end{array}$ & $\begin{array}{c}\text { Collective agreement } \\
\text { av. barg wage }\end{array}$ \\
\hline \hline av. actual wage & .901 & .949 \\
av. wage drift & .003 & .134 \\
dispersion actual wage & -.169 & -.008 \\
dispersion wage drift & -.169 & -.385 \\
\hline
\end{tabular}

Table 6: Correlation Between Bargained Wages And: ACtual Wage, Wage Drift And THEIR DISPERSION, AT DIFFERENT LEVELS OF AGGREGATION, 1999.

Notes: Correlations are weighted by the size of each group. The dispersion indicator is the coefficient of variation. Source: Computations based on Portugal, MTSS (1999). 


\begin{tabular}{|c|c|c|c|c|c|c|}
\hline & \multicolumn{2}{|c|}{ wage bargained } & \multicolumn{2}{|c|}{ wage drift } & \multicolumn{2}{|c|}{ wage actual } \\
\hline & (coef.) & (marg.) & (coef.) & (marg.) & (coef.) & (marg.) \\
\hline gender & $\begin{array}{l}-.109 \\
(.0007)\end{array}$ & -.062 & $\begin{array}{c}-.128 \\
(.0007)\end{array}$ & -.079 & $\begin{array}{c}-.204 \\
(.0007)\end{array}$ & -.177 \\
\hline schooling & $\begin{array}{r}.027 \\
(.0001)\end{array}$ & .016 & $\begin{array}{r}.030 \\
(.0001)\end{array}$ & .019 & $\begin{array}{r}.053 \\
(.0001)\end{array}$ & .047 \\
\hline age & $\begin{array}{r}.034 \\
(.0002)\end{array}$ & .020 & $\begin{array}{r}.018 \\
(.0002)\end{array}$ & .011 & $\begin{array}{r}.038 \\
(.0002)\end{array}$ & .034 \\
\hline age squared & $\begin{array}{r}-.0003 \\
(2.41 \mathrm{e}-06)\end{array}$ & -.0002 & $\begin{array}{r}-.0002 \\
(2.34 \mathrm{e}-06)\end{array}$ & -.0001 & $\begin{array}{r}-.0004 \\
(2.43 \mathrm{e}-06)\end{array}$ & -.0003 \\
\hline tenure & $\begin{array}{r}.007 \\
(.00005)\end{array}$ & .004 & $\begin{array}{r}.002 \\
(.00005)\end{array}$ & .001 & $\begin{array}{r}.007 \\
(.00005)\end{array}$ & .006 \\
\hline tenure less than 1 year & $\begin{array}{l}-.033 \\
(.0009)\end{array}$ & -.019 & $\begin{array}{r}-.038 \\
(.0009)\end{array}$ & -.024 & $\begin{array}{l}-.058 \\
(.0009)\end{array}$ & -.051 \\
\hline firm size $(\log )$ & $\begin{array}{r}.048 \\
(.0002)\end{array}$ & .028 & $\begin{array}{r}.012 \\
(.0002)\end{array}$ & .008 & $\begin{array}{r}.041 \\
(.0002)\end{array}$ & .036 \\
\hline firm age & $\begin{array}{r}-.0004 \\
(1.00 \mathrm{e}-05)\end{array}$ & -.0003 & $\begin{array}{r}-.0002 \\
(1.00 \mathrm{e}-05)\end{array}$ & -.0001 & $\begin{array}{l}-.0005 \\
(.00002)\end{array}$ & -.0005 \\
\hline firm av. labor productivity (log) & $\begin{array}{r}.044 \\
. .0003)\end{array}$ & .026 & $\begin{array}{r}.033 \\
(.0003)\end{array}$ & .021 & $\begin{array}{r}.064 \\
. .0003)\end{array}$ & .057 \\
\hline firm gross job flow rate & $\begin{array}{r}.002 \\
(.0006)\end{array}$ & .001 & $\begin{array}{r}.012 \\
(.0006)\end{array}$ & .007 & $\begin{array}{r}.016 \\
(.0007)\end{array}$ & .014 \\
\hline ag. multi-firm & $\begin{array}{l}.093 \\
(.004)\end{array}$ & .058 & $\begin{array}{r}-.025 \\
(.004)\end{array}$ & -.016 & $\begin{array}{l}-.017 \\
(.004)\end{array}$ & -.015 \\
\hline ag. sectoral & $\begin{array}{r}-.036 \\
(.003)\end{array}$ & -.022 & $\begin{array}{r}-.024 \\
(.003)\end{array}$ & -.016 & $\begin{array}{l}-.145 \\
(.003)\end{array}$ & -.132 \\
\hline ag. mandatory regime & $\begin{array}{r}-.150 \\
(.004)\end{array}$ & -.078 & $\begin{array}{l}.179 \\
(.004)\end{array}$ & .127 & $\begin{array}{l}-.023 \\
(.004)\end{array}$ & -.020 \\
\hline conc. ag. within occup. (Herfind.) & $\begin{array}{l}.112 \\
(.001)\end{array}$ & .065 & $\begin{array}{r}-.092 \\
(.001)\end{array}$ & -.058 & $\begin{array}{l}-.025 \\
(.001)\end{array}$ & -.022 \\
\hline conc. ag. within firm (Herfind.) & $\begin{array}{r}.263 \\
(.003)\end{array}$ & .153 & $\begin{array}{r}-.214 \\
(.003)\end{array}$ & -.135 & $\begin{array}{l}-.013 \\
(.003)\end{array}$ & -.011 \\
\hline conc. ag. within region (Herfind.) & $\begin{array}{r}-.032 \\
(.011)\end{array}$ & -.019 & $\begin{array}{r}-.063 \\
(.011)\end{array}$ & -.040 & $\begin{array}{r}-.183 \\
(.011)\end{array}$ & -.161 \\
\hline geog. scope agr. (number regions) & $\begin{array}{l}-.005 \\
(.0001)\end{array}$ & -.003 & $\begin{array}{r}.010 \\
(.0001)\end{array}$ & .006 & $\begin{array}{r}.002 \\
(.0001)\end{array}$ & .002 \\
\hline size col. agreement (log) & $\begin{array}{l}-.035 \\
(.0004)\end{array}$ & -.021 & $\begin{array}{r}.008 \\
(.0004)\end{array}$ & .005 & $\begin{array}{l}-.008 \\
(.0005)\end{array}$ & -.007 \\
\hline Obs. & 1134427 & & 1134427 & & 1134427 & \\
\hline Log likelihood & -403240.9 & & -362584.8 & & -372350.1 & \\
\hline $\mathrm{R} 2$ & 0.54 & & 0.30 & & 0.59 & \\
\hline$\hat{\sigma}$ & .301 & & .312 & & .327 & \\
\hline
\end{tabular}

Table 7: Tobit Model, BARGAIned WAGE AND WAGE DRIFT, 1999.

Source: Computations based on Portugal, MTSS (1999). Note: Three regional dummy variables and 15 industry dummy variables have been included in each regression. Standard-errors in parenthesis. 


\begin{tabular}{lrrr}
\hline \hline Variable & (coef.) & (std. err.) & (marg.) \\
\hline gender & -0.113 & $(0.001)$ & -.065 \\
schooling & 0.032 & $(0.0001)$ & .018 \\
age & 0.044 & $(0.0002)$ & .026 \\
age squared & 0.0004 & $(0.000)$ & -.0003 \\
tenure & 0.010 & $(0.000)$ & .006 \\
tenure less than 1 year & -0.036 & $(0.001)$ & -.021 \\
gender*union power & 0.016 & $(0.002)$ & .009 \\
schooling*union power & -0.015 & $(0.0003)$ & -.009 \\
age*union power & -0.027 & $(0.001)$ & -.016 \\
age squared*union power & 0.0004 & $(0.000)$ & .0002 \\
tenure*union power & -0.009 & $(0.0001)$ & -.005 \\
tenure less than 1 year*union power & 0.026 & $(0.003)$ & .015 \\
firm size (log) & 0.049 & $(0.0002)$ & .028 \\
firm age & -0.001 & $(0.000)$ & -.0003 \\
firm av. labor productivity (log) & 0.043 & $(0.0003)$ & .025 \\
firm gross job flow rate & 0.0002 & $(0.001)$ & -.0001 \\
ag. multi-firm & 0.109 & $(0.004)$ & .069 \\
ag. sectoral & -0.037 & $(0.003)$ & -.022 \\
ag. mandatory regime & -0.144 & $(0.004)$ & -.075 \\
concent. ag. within occupation (Herfindhal) & 0.839 & $(0.011)$ & .489 \\
concent. ag. within firm (Herfindhal) & 0.257 & $(0.003)$ & .150 \\
concent. ag. within region (Herfindhal) & -0.011 & $(0.011)$ & -.006 \\
geog. scope agreement (number regions) & -0.005 & $(0.0001)$ & -.003 \\
size col. agreement (log) & -0.036 & $(0.0004)$ & -.021 \\
Obs. & & 1134427 & \\
Log likelihood & & -395033.5 & \\
R2 & & 0.55 & \\
$\hat{\sigma}$ & .299 & \\
\hline \hline
\end{tabular}

Table 8: TOBit MOdel, BARGAINED WAGE: WORKER ATTRIBUtes INTERACTED WITH DEGREE OF UNION POWER, 1999.

Source: Computations based on Portugal, MTSS (1999). Note: Three regional dummy variables and 15 industry dummy variables have been included in each regression. 


\begin{tabular}{lcc}
\hline \hline \multicolumn{1}{c}{ variable } & mean & std. dev. \\
\hline bargained wage (log) & 11.35 & 0.38 \\
wage drift (log) & 0.33 & 0.33 \\
gender & 0.4 & \\
schooling & 7.34 & 3.81 \\
age & 36.08 & 11.07 \\
tenure & 7.86 & 8.80 \\
tenure less than 1 year & 0.17 & \\
firm size (log) & 4.53 & 2.37 \\
firm age & 21.63 & 23.5 \\
firm av. labor productivity (log) & 9.17 & 1.24 \\
firm gross job flow rate & 0.15 & 0.5 \\
ag. multi-firm & 0.05 & \\
ag. sectoral & 0.86 & \\
ag. mandatory regime & 0.04 & \\
concent. ag. within ind. (Herfindhal) & 0.69 & 0.3 \\
concent. ag. within firm (Herfindhal) & 0.97 & 0.1 \\
concent. ag. within region (Herfindhal) & 0.07 & 0.04 \\
geog. scope agreement (number regions) & 14.51 & 5.25 \\
size col. agreement (log) & 10.38 & 1.24 \\
\multicolumn{2}{c}{$\mathrm{N}$} & 1134427 \\
\hline \hline
\end{tabular}

Table 9: Descriptive statistics, Regression DATA, 1999. Source: Computations based on Portugal, MTSS (1999). 

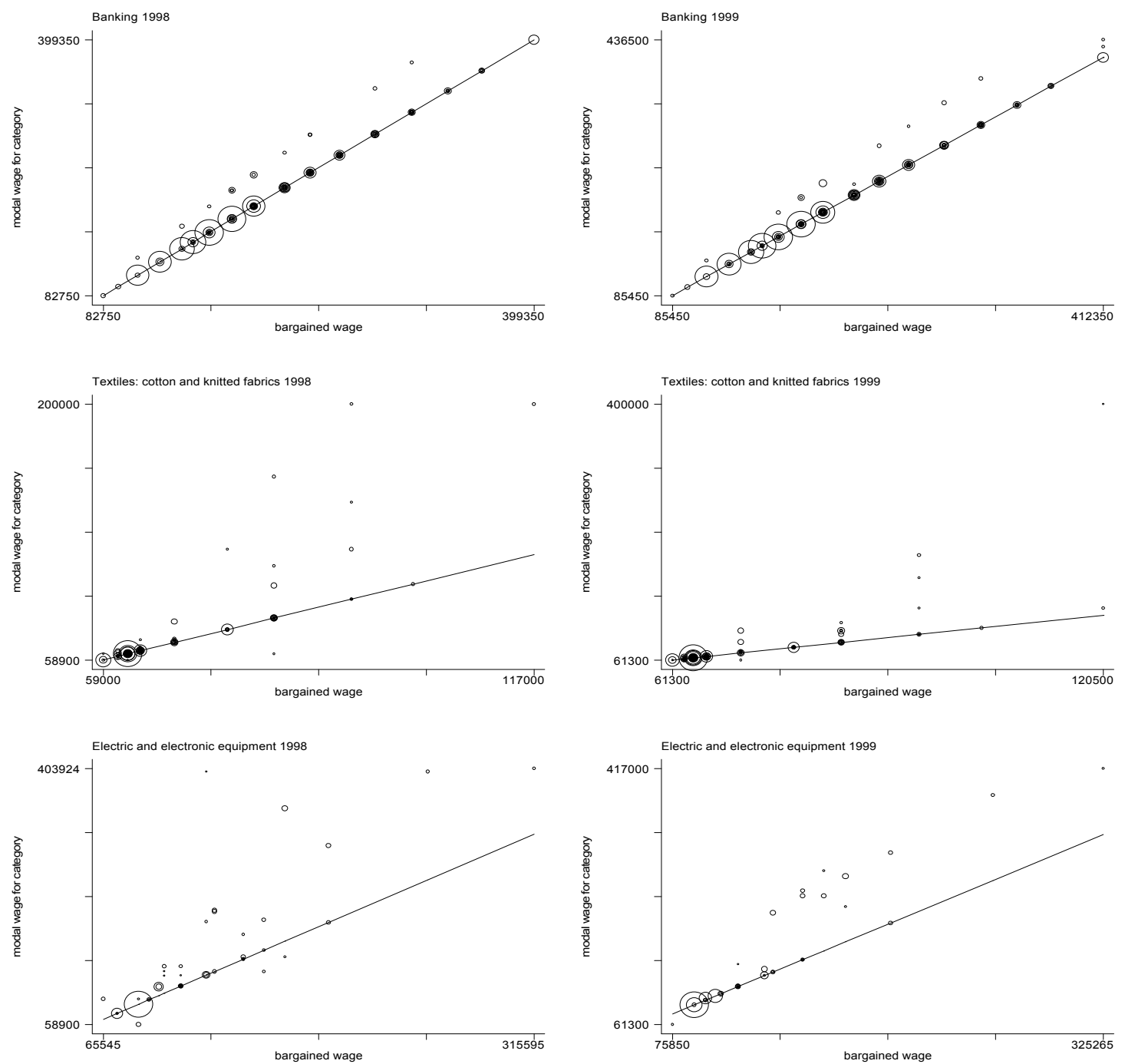

Figure 1: CONTRACTUAL WAGE VERSUS MODE OF THE BASE-WAGE BY WORKER PROFESSIONAL CATEGORY.

Note: Each circle represents one worker professional category and its area is proportional to the number of workers covered. Source: Computations based on Portugal, MTSS (1998-1999) and Boletim do Trabalho e Emprego (several numbers). 

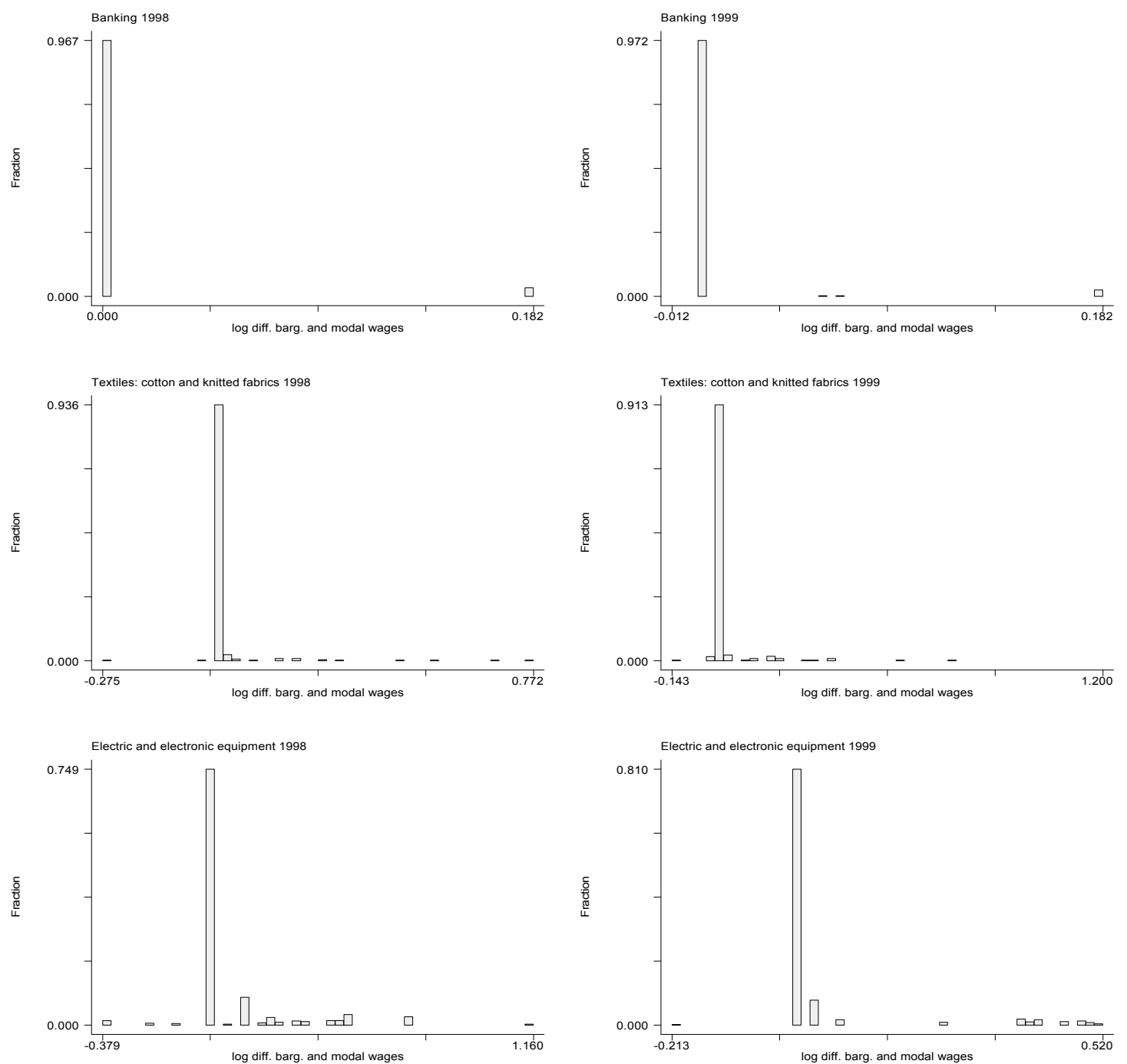

Figure 2: SHARE OF WORKERS WHOSE CONTRACTUAL WAGE IS ACCURATELY INFERRED USING THE MODE OF THE DISTRIBUTION OF BASE-WAGES FOR THE PROFESSIONAL CATEGORY.

Source: Computations based on Portugal, MTSS (1998-1999) and Boletim do Trabalho e Emprego (several numbers). 


\section{IZA Discussion Papers}

\begin{tabular}{|c|c|c|c|c|}
\hline No. & Author(s) & Title & Area & Date \\
\hline 900 & $\begin{array}{l}\text { M. C. Berger } \\
\text { G. C. Blomquist } \\
\text { K. Sabirianova Peter }\end{array}$ & $\begin{array}{l}\text { Compensating Differentials in Emerging Labor } \\
\text { and Housing Markets: Estimates of Quality of } \\
\text { Life in Russian Cities }\end{array}$ & 4 & $10 / 03$ \\
\hline 901 & $\begin{array}{l}\text { P. F. Orazem } \\
\text { M. Vodopivec }\end{array}$ & $\begin{array}{l}\text { Do Market Pressures Induce Economic } \\
\text { Efficiency: The Case of Slovenian } \\
\text { Manufacturing, 1994-2001 }\end{array}$ & 4 & $10 / 03$ \\
\hline 902 & $\begin{array}{l}\text { P. Frijters } \\
\text { M. A. Shields } \\
\text { S. Wheatley Price }\end{array}$ & $\begin{array}{l}\text { Immigrant Job Search in the UK: Evidence from } \\
\text { Panel Data }\end{array}$ & 1 & $10 / 03$ \\
\hline 903 & $\begin{array}{l}\text { S. Girma } \\
\text { H. Görg }\end{array}$ & $\begin{array}{l}\text { Evaluating the Causal Effects of Foreign } \\
\text { Acquisition on Domestic Skilled and Unskilled } \\
\text { Wages }\end{array}$ & 2 & $10 / 03$ \\
\hline 904 & $\begin{array}{l}\text { S. P. Jenkins } \\
\text { P. Van Kerm }\end{array}$ & $\begin{array}{l}\text { Trends in Income Inequality, Pro-Poor Income } \\
\text { Growth and Income Mobility }\end{array}$ & 1 & $10 / 03$ \\
\hline 905 & $\begin{array}{l}\text { D. Weichselbaumer } \\
\text { R. Winter-Ebmer }\end{array}$ & $\begin{array}{l}\text { Rhetoric in Economic Research: The Case of } \\
\text { Gender Wage Differentials }\end{array}$ & 7 & $10 / 03$ \\
\hline 906 & $\begin{array}{l}\text { D. Weichselbaumer } \\
\text { R. Winter-Ebmer }\end{array}$ & $\begin{array}{l}\text { A Meta-Analysis of the International Gender } \\
\text { Wage Gap }\end{array}$ & 7 & $10 / 03$ \\
\hline 907 & $\begin{array}{l}\text { A. Dupuy } \\
\text { L. Borghans }\end{array}$ & $\begin{array}{l}\text { Supply and Demand, Allocation and Wage } \\
\text { Inequality: An International Comparison }\end{array}$ & 1 & $10 / 03$ \\
\hline 908 & M. Leonardi & Product Demand Shifts and Wage Inequality & 1 & $10 / 03$ \\
\hline 909 & M. Leonardi & $\begin{array}{l}\text { Firm Heterogeneity in Capital/Labor Ratios and } \\
\text { Wage Inequality }\end{array}$ & 1 & $10 / 03$ \\
\hline 910 & $\begin{array}{l}\text { P. Díaz-Vázquez } \\
\text { D. Snower }\end{array}$ & $\begin{array}{l}\text { On-the-Job Training, Firing Costs and } \\
\text { Employment }\end{array}$ & 5 & $10 / 03$ \\
\hline 911 & J. Wagner & $\begin{array}{l}\text { Are Nascent Entrepreneurs Jacks-of-All-Trades? } \\
\text { A Test of Lazear's Theory of Entrepreneurship } \\
\text { with German Data }\end{array}$ & 5 & $10 / 03$ \\
\hline 912 & $\begin{array}{l}\text { D. Checchi } \\
\text { A. Filippin }\end{array}$ & An Experimental Study of the POUM Hypothesis & 1 & $10 / 03$ \\
\hline 913 & $\begin{array}{l}\text { S. Pivnenko } \\
\text { D. DeVoretz }\end{array}$ & $\begin{array}{l}\text { The Recent Economic Performance of Ukrainian } \\
\text { Immigrants in Canada and the U.S. }\end{array}$ & 1 & $10 / 03$ \\
\hline 914 & $\begin{array}{l}\text { A. R. Cardoso } \\
\text { P. Portugal }\end{array}$ & $\begin{array}{l}\text { Bargained Wages, Wage Drift and the Design of } \\
\text { the Wage Setting System }\end{array}$ & 5 & $10 / 03$ \\
\hline
\end{tabular}

An updated list of IZA Discussion Papers is available on the center's homepage www.iza.org. 